\title{
SELECTION CRITERIA PREDICTIVE OF ACADEMIC SUCCESS IN THE FIRST TWO YEARS OF THE INTEGRATED DIPLOMA IN NURSING
}

LR UYS

\section{INTRODUCTION}

Student wastage during basic nursing programmes has been estimated at between $20 \%$ and $47 \%$ per annum over the last 10 years (Kotze, 1987; SANA, 1983). The training of every student costs the state approximately R13 500 per annum according to an investigation done by the SA Nursing Association in 1987. The economic loss due to the student wastage is therefore significant. At the same time student numbers are declining at a time during which many more nurses are necessary to maintain the ratio of registered nurses to the population (Kotze, 1987). The student wastage therefore also has serious implications for the health services.

Since training schools usually receive more applications than can be accommodated as students, the process of selection becomes a key factor in selecting students who will complete the programme and join the professional nursing cadre.

\section{LITERATURE SURVEY}

Very little research has been published on the topic of the selection of student nurses in South Africa.

In a survey done in six nursing schools for Black nurses, Mashaba (1985) describes the criteria used for selection of students. This includes specific subjects (especially biology, language, maths and sciences) citizenship or area of residence, a good testimonial, the aggregate matric symbol, and good health.

The first study on the efficacy of a selection technique was done by van Huyssteen and Folscher (1978). They tested the ability of both an academic achievement measure and a structured interview to predict both academic success and wastage from a basic nursing degree programme. Although no statistical analysis was done, there seemed to be indications that the academic measure predicted failure. Data from the interviews were too limited to come to any conclusions. Students with Maths, Science and Biology seemed to produce more passing students than would be expected from the general ratio.

In 1989 Basson and Botes reported on a further study with a similar group of students, in which the cut-off points for selection with two different scales were established.

A study done on degree students at the University of the Orange Free State (1980) over a period of a few years in which the possibility of using personality testing to predict student wastage, showed that none of the $16 \mathrm{PF}$ fields showed any predicative ability, except the scale which measured anxiety tolerance.

The only reported study aimed at diploma nursing students was a national survey which showed that the total matriculation examination marks, the marks for the home language, the marks for the subject group geography, Biblical studies, economics and history, and the marks for maths, biology and science could predict success in nursing programmes (Stoker et al, 1985). Since this study was done before the introduction of the integrated diploma programme, it is not clear whether its results are still valid.

The question of what should be looked at when selecting students therefore is still a very open one, especially with regard to factors other than academic performance.

\section{RESEARCH APPROACH}

This was a correlation study in which all students accepted by the Natal College of Nursing were expected to fill in a selection questionnaire during registration. Factors on the questionnaire were then correlated with their results in the programme over the four years of its duration. In this way it was planned to identify which of these items correlated significantly with programme outcomes.

\section{Instrumentation}

In this study the selection instruments used by the five campuses of the Natal College of Nursing were combined into one questionnaire, covering the following aspects:

School history, e.g. participation in sport, societies and hobbies; leadership; subjects; attitudes to school and teachers.

Job history, if any. Post-school experience. Family background e.g. marital status and parity; family of origin; living away from family.

Career choice e.g. support from family; strength and reasons for choice; influences; expectations and knowledge of nursing.

The instrument was drafted by a committee and tested on students already in the programme.

\section{Sample}

All students registering for the diploma programme at the five main campuses of the College from January 1988 to July 1988 were included in the sample. They were all required to fill in the biographical questionnaire, and al their examination results were collected.

\section{RESULTS}

\section{Sample description}

The sample consisted of 439 students from the five campuses of the college.

King Edward campus teaches black students, Addington and Greys white and coloured students and RK Khan and Northdale Asian students.

Of the 439 students who commenced their training, 62 dropped out during their first year, 6 at the end of their first year, and 16 during their second year - a total of 84 drop-outs. Of these only 15 were excluded for academic reasons according to college exclusion rules.

The results of all the first year subjects were added into one score, and that was correlated with the different items in the questionnaire. The same was done with the second year results. All statistics were carried out using the SPSS statistical package.

\section{School history}

The high schools that the students came from were categorized according to the authority which administered them. The sports in which they participated, were classified in terms of individual or team sport. The societies were categorized as to their focus, e.g. religious, ecological, academic, or political/cultural. The hobbies were categorized in terms of 
Table 1 : Sample distribution by campus

\section{Frequency}

52

157

Greys

91

92

47

Percent

Addington

RK Khan

Northdale

whether they were solitary or social, as well as whether they were active or passive. Table 2 summarizes the results of the correlation between these items and performance.

As far as the school authority is concerned, it is important to note that both coloured and white schools are represented in the different categories of marks according to their numbers. Black schools are slightly over-represented in the failing category $(1-49 \%)$, but their real over-representation is in the categories 50 to $59 \%$ (14 as opposed to 9 students), and 60 to $69 \%$ (27 as opposed to 23 students). As far as the Asian schools are concerned, they are over-represented in the categories $60 \%$ plus (see table 3 ). Students from coloured schools seem to do worse than those from black schools in terms of promotion to second year (5 were not promoted instead of the expected 1,4 ; with the black school producing 6 instead of 3). All other groups are proportionate or more positive in this regard.

This influence of the school seems to only influence first year achievement.

The type of sport and society participated in and the level of that participation, do not play a significant role in first and second year results. However, there seems to be some trend that the societies in which students participate, is significant, since the second society mentioned by students correlates significantly with second year results. The kind of society that seems positively to influence performance is of social, humanistic or academic variety, while religious and performing arts groups influence results negatively. Political/cultural and ecological societies seem to be neutral.

The kind of hobbies the students have seems to have a significant influence. Students with a solitary passive hobby such as reading and watching television as first choice seem to supply significantly more of the $70 \%+$ performances (13 as opposed to the expected 6) than students with other types of hobbies. Students with a first choice of an active social hobby such as dancing or tennis supply significantly more of the failures ( 2 as opposed to the expected ,4).

Only $55,2 \%$ of the students were not prefects, deputy head girl/boy or head girl/boy. This leadership group is under-represented in all percentage-categories except $70 \%+$, while the non-leadership group shows the opposite pattern.

Students who claim to have liked school very much are under-represented in the drop-out group, while all the other types of responses are over-represented. Students whose favourite subjects were either English or biology drop out significantly less than others, while students with a favourite of home-economics drop out significantly more. It is only in first year results where the type of teacher preferred makes a statistically significant impact. It would seem that students who prefer a teacher who was strict and supervised the work will more probably fall into the lower categories of marks, while students who prefer a teacher who did some supervision and left some work up to the individual, would more likely fall into the two highest categories, while choice of the teacher that gave the student the responsibility had no influence on scores.

As far as school subject performance is concerned, it is interesting to note that biology, history and the two maths/science/biology combinations seem to lose predictive ability at the end of the first year. Students with the following symbols in Std.X will probably not fail the first year:

English: A or B

Maths: A, B, C, or D

Science: any symbol

Biology: any symbol

History: B and C does best, then A

It is important to note that each of these subjects predicts on its own and not as part of a combination.

\section{Job and post-school experience}

Having had a holiday or part-time job or a post secondary qualification did not significantly correlate with the outcomes. However, work experience had a significant influence. The students with work experience contribute double their proportion to the failing grades in the second year, and less than their proportion

Table 2 : Significant correlations between school history and results.

\begin{tabular}{|c|c|c|c|c|c|}
\hline & $\begin{array}{c}\text { First year } \\
\text { results }\end{array}$ & $\begin{array}{l}\text { Promoted } \\
\text { to } 2 \mathrm{nd} \text { yr }\end{array}$ & $\begin{array}{l}\text { 2nd yr } \\
\text { results }\end{array}$ & $\begin{array}{l}\text { Promoted } \\
\text { to } 3 r d \text { yr }\end{array}$ & $\begin{array}{c}\text { Dropped } \\
\text { out }\end{array}$ \\
\hline High school &, 0447 &, 0033 & - & - & - \\
\hline Sport & - & - & - & - & - \\
\hline Level of partic & - & - & - & - & - \\
\hline Society & - & - & - & - & - \\
\hline Level of partic & - & - & - & - & - \\
\hline Hobbies &, 0775 & - & 0330 & - & - \\
\hline Perfect/leadership &, 05 & - & - & - & - \\
\hline Liking for school & - & - & - & - & 0143 \\
\hline Subject liked best & - & - & - & - & 0201 \\
\hline $\begin{array}{l}\text { Type of teacher } \\
\text { preferred }\end{array}$ &, 0197 & - & - & - & - \\
\hline English &, 0001 &, 0064 &, 0005 & - & - \\
\hline Maths &, 0047 & - & ,0523 &, 0217 & - \\
\hline Science &, 0329 & - &, 0115 & - & - \\
\hline Biology &, 0002 & - & - & - & - \\
\hline History &, 0000 & ,0000 & - & - & - \\
\hline Goography & - & - & - & - & - \\
\hline $\begin{array}{l}\text { Maths, Science and } \\
\text { Biology }\end{array}$ &, 0197 & - & - & - & - \\
\hline $\begin{array}{l}\text { Maths, Science, Biol } \\
\text { and Eng }\end{array}$ & 0551 & - & - & - & - \\
\hline
\end{tabular}


Table 3 : First year results and high school authority

$\begin{array}{lrrrrr} & \text { Black } & \text { Coloured } & \text { White } & \text { Asian } & \text { Private } \\ 1-49 \% & 2(1,4)^{*} & 1(, 5) & 6(6) & 0(1) & 0(0) \\ 50-59 \% & 14(8) & 3(3) & 38(38) & 0(4,5) & 1(2) \\ 60-69 \% & 27(23) & 7(7,9) & 97(97) & 8(12) & 7(5,4) \\ 70 \%+ & 13(23) & 8(8) & 97(96) & 21(12) & 5(5) \\ \text { Column \% } & 15,8 & 5,4 & 67 & 8,2 & 3,7 \\ \text { * expected frequency in brackets. } & & & & \end{array}$

to the $70 \%+$ grades. The students with no work experience show the opposite picture. As far as the length of work experience is concerned, it seems as though experience of up to one year and over four years do not have a negative influence, but experience of between 1 and four years decreases achievement.

\section{Family background}

The following items show no significant correlation with achievement.

- marital status of student,

- number of children he/she has,

- ages of these children,

- the student's position in his/her family of origin,

- whether she/he went to boarding school or lived away from home,

- whether she/he has spent holidays away from home or lived in an institution,

- whether she/he will be able to spend weekends at home,

- father's occupation.

There is a significant correlation between the mothers' occupation and the student dropping out $(, 0447)$. It would seem that students whose mothers are unemployed are not likely to drop out, while students whose mothers are lower white collar workers are more likely to drop out. Other types of occupations do not seem to have an influence.

The number of children in the student's family of origin correlates significantly with both promotion to second year $(, 0371)$ and exclusion for academic reasons $(, 0357)$. It would seem that families with up to four children have a neutral or positive effect on achievement, families with five to seven children have a negative effect, and eight and over is neutral.

\section{Career choice}

The following aspects of the choice of the choice of nursing as a career did not show a significant correlation with achievement:
- parents' reaction to choice,

- how sure the student was about the choice of nursing,

- what other careers she/he considered,

- agreement with the statements that nursing is physically hard work and includes lots of academic work,

- a parent who is a nurse,

- an aunt who is a nurse,

- doing cadet nursing,

- what aspect of nursing found the most unpleasant.

When questioned about what influenced them to do nursing, students often gave more than one answer. Answers were classified into different categories, such as social influence (somebody influenced the student), a positive image of nursing (liked their smart uniforms), etc. Although no significant correlation was found with the first reason students gave, the second one gave a significant correlation $(, 0258)$ with promotion to second year. On investigation it was found that students who mentioned choosing nursing for a specific aspect of it, such as paediatrics or midwifery, were more likely not to be promoted to second year.

With regard to the question of why they chose nursing, a significant correlation was found with dropping out, and an almost significant one with second year results. On looking at the reasons given, it was found that students who mention helping or caring, or the challenge and interest of nursing did best, while students who mention an interest in medicine did the worst.

Having either a sibling $(, 0539)$ or a friend $(, 0065)$ who was a nurse positively influenced promotion to the second year.

\section{Campus}

Since it was thought that some of these factors might have an influence only in one campus, the correlations for the two Asian campuses were calculated separately. It was found that
- doing enrolled nursing, many items lost their significance, especially since so few Asian students appeared in the low achievement categories, and no items that were not significantly correlated for the whole group was significant for this subgroup.

\section{DISCUSSION AND CONCLUSIONS}

The influence of the school authority on achievement, although interesting, cannot assist much with selection, since students from all authorities are necessary to fill the nursing needs of the country. However, it could direct student support services to groups which need it most. In this regard it would seem that coloured students seem to be failing subjects essential for promotion, while black students seem to need assistance with achieving more than average.

There are quite a number of factors which influence success in the first year, but lose their predictive ability by the second year. Although these factors therefore should be considered, they should not be over-emphasized. The influence of biology for the first year might relate to Anatomy and Physiology being an important first year subject. Other items may make it easier for students to adapt to the new environment, and in this way enhance achievement. An example of this kind of item is the leadership the student has shown at school, and the preference for more independent learning. It might also be that students who have not worked for long adapt more easily to the discipline of nursing, while the ones who have come to nursing after many years of working are highly motivated and more mature. It would also seem that peer group members in nursing have a more positive influence on nursing students than either parents or adult family members in terms of either the information they give about nursing being more relevant or the support they give being more appropriate.

Long-standing habits or preferences seem to gain more influence in second year performance. For instance, a liking for school, or for certain subjects, hobbies or societies come into play which the initial adaptation to the new situation has taken place. It would be interesting to see whether a different constellation of factors comes into play during the senior years. As far as school subjects are concerned, one could hypothesise that achievement in maths and science plays a role not because of any specific knowledge they give, but rather because the brighter students are usually steered into taking these subjects.

Based on these results, it is recommended that the following factors be taken into account when students are selected, according to the weights stated next to them:

- leadership position +1

- English A or B +2

- Maths any symbol +2 
- Science any symbol +2

- Biology any symbol +1

- History A, B or C +1

- Type of teacher preferred: strictly supervises- -1

- some supervision +1

- Work experience 1 to 4 years -1

- Chose nursing because of liking for specific aspect -1

- Liked school very much +1

- Favourite subject either English or Biology +1

- Belongs to the following societies: social, humanistic, academic +1

- religious, performing arts -1

- Hobbies: solitary passive +1

- social active -1

- Has a sibling or friend in nursing +1

- Number of children family of origin 5 to $7-1$
These recommendations cannot be seen as final, since the third and fourth year results might alter them.

\section{ACKNOWLEDGEMENT}

The assistance of the Natal College of Nursing Staff in gathering and computerizing the data was greatly appreciated.

\section{REFERENCES}

Basson, $\mathrm{A}$ and Botes, A Die gebruik van die Sweedse Skaal by die keuring van verpleegkunde studente aan die Randse Afrikaanse Universiteit Curationis 12(3+ 4) :51-56, Dec.1989.

Kotzé, W J Tendense in die verpleegberoep: aspekte vir oorweging, 1987 Curationis 10(4) :4-10, Dec. 1987.

Mashaba, T G The education and training of the Black nurse in South Africa 1900-1982 Unpublished D Litt et Phil dissertation at UNISA, Pretoria, 1985.

SA Nursing Association Verslag oor die verpleegdiens en verpleegonderrig in die Republie van Suid-Afrika. Pretoria, SANA, 1983.
Stoker, D J e.a Ondersoek na differensiële toelatingsvereistes tot tersiêre onderwysintigtings WS32. Pretoria, HSRC, 1985.

University of the Orange Free State Die gebruik van 'n persoonlikheidstoets by die keuring van verpleegkunde studente. Unpublished study done by the Departments of Nursing and Psychology, UOFS, Bloemfontein, 1980.

van Huyssteen, MC and Folsher, CW Die keuring van studentverpleegkundiges aan die Randse Afrikaanse Universiteit - 'n oorsig Curationis 1(3) : 24-30, Dec. 1978.

Professor LR Uys

Head: Department of Nursing UNIVERSITY OF NATAL, DURBAN. 